\title{
THE IMPACT OF OIL PRICE ON STOCK MARKET:EMPIRICAL EVIDENCE FROM US
}

\author{
Shanaz hakim , \\ University of Sulaimania ,Faculity of Economics and Administration, Department of Economy, ,Sulaimani-New \\ capm-Tasluja-Street 1-Zone 501,Iraq \\ Tugut Tursoy,
}

Head of the Department of Banking and Finance, Faculty of Economics and Administrative

Science ,Near East University,Nicosia,99138,North Cyprus, Mersin 10 - Turkey

\begin{abstract}
The analysis of this research focuses on the interactive relationship among the fluctuation of crude oil prices, the real GDP and the stock market of United State. This empirical investigation uses data is in between 1990 and 2018 with the Vector Auto-regression (VAR) analysis, and multiple regressions with its assumption were used in order to analyses data.

Findings, oil price and economic growth are very important determinates of stock market in US because the $p$-value of this were less than the common alpha $\alpha=0.05$. For instance, the crude oil price had positive impact on stock market because for each unit increasing of crude oil price, the stock market will increase by $(0.276901)$ after holding all other variable constant. However, we find that GDP has negative impact on the participations of increasing the stock market.
\end{abstract}

Keywords: Stock market, oil prices, real GDP growth,US

\section{Introduction}

The stock market can be seen as a determinative factor of economic strength and development in every country. Additionally, the dynamics of crude oil price has a great impact on modifying economic activities and both consumption and production of oil at the stock market Kilian and Park 2009).
Accordingly, these variables have been capturing a great amount of economist's attention in terms of evaluating the relationship between crude oil prices and equity markets.

It is well documented that the volatility shocks in the crude oil sectors have a considerable impact on various economic activities as well as on financial markets. In the last few years, much empirical research has concentrated on the reasons for change in the behaviour of the equity markets or its structural breaks. These studies show that share prices have experienced some periods in which their characters seem to shift dramatically. Well-known examples include: the price rises of crude oil in 1973-1974, the equity market crash of 1987, the 'Iraqi invasion of Kuwait' in 1990, the East Asian countries' currency crisis of 1997, the terrorist attack of 11th of September 2001, the increase of crude oil prices in 2007-2008 and finally, the global financial crisis in 2008-2009. All these events led to shifts in the dynamic process of financial time series (Aloui and Jammazi, 2009).

The significant role of oil in an economy has implied that shifts in the price of oil are related to shifts in equity prices; however, such a change is distinct across stock indices and stock markets react differently from one nation to another. Yet the effects of changes in oil prices on share markets differ depending on whether the country is an oil-exporter or an oil-importer (Huang et al, 1996).

This research paper aims at investigating the impact of oil price upon stock market in United State. 
Additionally, a macroeconomic variable is included: real GDP growth.

\section{Literature Review:}

Over the past three decades, oil is one of the most significant energy resources worldwide and is known for wide price movements; it has also enjoyed a strategic position in affecting macroeconomic activities. The dependency on crude oil has grown universally in the 'supply-demand equilibrium' (Kapusuzoglu, 2011). Therefore, large numbers of scholars have studied the link between macroeconomics-oil price connections and long-run stock price-oil price relationships.

Hamilton (1983) provided evidence of linkages between economic output and the price of oil, and further suggested that oil prices were the well-known cause for each "post-World War II" (1947-1972) economic downturn in the USA. Moreover, Hamilton (2003) indicates that although until 1973 there was stability in the movement of oil prices, since then, the effect of oil price changes on the economic world has been harsher. He also found a strong negative correlation between future GDP growth and rises in the oil price.

The crucial function of oil in an economy would suggest that changes in the oil price could be associated with shifts in the price of stock market (Hung et al., 1996). The relation between stock market and oil prices arises from crude oil prices are being frequently used as exogenous variables regarding the economy. While studying them, an attempt to look for correlations between oil and stock prices was made by Gisser and Goodwin (1986), who found that a rise in the oil price would influence cash flow, since such a variable is a vital input employed in producing many goods and services. With an oil price increase, the production cost will therefore increase where there is no 'substitution possibility', which in turn increases commodity prices, prompting a decline in the stock price. In addition, an increase in oil prices will lead to inflation pressure; this leads central banks implementing a rule of increasing the rate of interest in order to beat inflation. More rises in interest rates will lead bonds and treasury bills to be more preferable than equities, this causes more decline in stock prices.

In order to evaluate the correlation between stock market and oil markets of four developed countries, the USA, UK, Canada and Japan, Jones and Kaul (1996) employed quarterly data and utilised simple regression models. They found that stock returns of the US, Canada were negatively affected by the shocks of oil price; however, the results were not strong in Japan or the UK. Likewise, after applying an unrestricted VAR investigation and using monthly data from January 1947 to April 1996, Sadorsky (1999) investigated the effect of shocks of oil prices on the US index. The findings revealed that, in the short-run, stock and oil prices had a negative correlation, which meant that higher oil prices resulted in lower stock returns.

Park and Ratti (2008) investigated the impact of oil prices on the stock markets of the U.S. and thirteen European regions. The study employed data for the period between 1986-2005, in which the VAR approach was performed. The result showed that the dynamics of oil prices generally have an effect on security markets; in Norway stock prices increased along with the increase in oil prices. The findings also indicated that the rise in the volatility of oil prices have statistically significant negative impacts on the stock markets in the US and many European counties.

Kilian and Park (2009) applied VAR with data on the US stock market, oil production and shipping activity as proxies for supply and demand. The authors examined the different shocks' effects on the US stock market. However, they found very little contemporaneous explanatory power (less than $2 \%$ combined) and mostly focused on shifts in oil prices associated with neither aggregate demand nor supply. The essential demand and supply shocks were determined by underlying inventions to the actual oil price. Thus, influenced by the underlying causes of oil price growth, the reaction of the USA actual equity returns to the shocks of oil price varied virtually. 
In order to assess the long-term and causality analysis for Turkey's stock exchange and world crude oil prices, Kapusuzoglu (2011) applied econometric models, using daily data for the period of 2000-2010, and the Istanbul Stock Exchange (ISE) National 30, National 50, National 100 Index and world oil prices. The results indicated causal co-integration between world oil prices and each stock index in the long-run. However, granger causality results displayed a oneway causality correlation for each share index towards world oil prices, whilst world oil prices were not causal for any indices.

Despite the above, some argue that there is no correlation between stock and oil markets, or, if the correlation exists, it is possibly not strong. For instance, Wei (2003) argues that the fall in the US stock price of 1974 cannot be the result of the oil price shocks of 1973-1974. The study of Chen, Roll and Ross (1986) was one of the first researchers to methodically examine the effect of macroeconomic factors on stock markets. Their findings showed that the stock market was influenced by inflation rates, interest rates, industrial production and bond yields; but stock prices did not react to changes from oil prices.

In his study, Maghyereh (2004) examined the impact of oil price shocks on the equity returns of twentytwo emerging countries, applying the unrestricted VAR estimation suggested by Sim (1980), with daily data. The findings showed that the effect of oil price shocks was not meaningful on the equity returns of the nations. However, when the author tested variance decomposition and impulse response, and examined the efficiency of 'innovations transmission' from oil sectors to the stock exchanges. The results showed that there is a response to movements in oil price following each stock market plot. The impulse response demonstrates a gradual spread of innovations from the oil sector into the stock sectors. According to the results, the gradual adjustment implies evidence of inefficiency in the emerging indices transitions of innovations from the oil sector. In addition, the author argues that the stock market is ineffective to the shocks of oil prices, because the magnitudes of responses are not large.
In addition to the studies on the relation of oil price to macroeconomics and oil prices to stock exchanges, there is also research that analyse the relationship between stock market and economic growth (i.e. real GDP growth). For instance, Hamid and Sumit (1998) used a dynamic panel method for a sample period of 21 years to test the connection between stock market and economic developments of 21 emerging markets. The findings suggest direct and indirect positive relations between economic growth and some indicators of equity markets' performance by boosting the behaviour of private investment. Applying the Granger Causality test and regression analysis, Adam and Sanni (2005) investigated the role of equity markets in the economic growth of Nigeria. In the study one-way causality between market capitalisation and GDP growth and two-way causality between market turnover and GDP growth was found. The study also indicates a positive correlation between turnover ratios and GDP growth. Further, to examine the correlation between stock exchange and economic development in France for the period of 1965-2007, Vazakidis (2009) used the VAR model to investigate causal relations between both variables. The study indicated that economic growth caused the movement of equity markets; that is, the effect was positive.

As has been shown throughout this section, there are many studies investigating the relation between stock market and oil. The result of these findings varies among nations. Most of these have discovered that there is a link between stock market and oil prices, but some have found a negative correlation, some positive, while others suggest no causal relationship between the variable.

\section{Methodology}

The study used the Vector Auto-regression (VAR) method in the regression analysis with its assumptions in order to investigate the impact of same variable such as (crude oil price, GDP) on stock market in US. The dependent variable in this study was (stock market) and also the independent 
variables were (GDP, oil price). The data main source is "World Development Indicators published by the World Bank and available at: databank.worldbank.org. Also, stock market (DJNES industrial average) is obtained from Macro trends. In sum, in this study the following steps are performed to estimate the influence of oil price on stock market in US for time period 1990 to 2018, to find the result.

Table 1: Summary statistics of world crude oil prices: 1990-2018.

\begin{tabular}{|c|c|}
\hline & World oil price \\
\hline Mean & 40.20 \\
\hline Maximum & 98.99 \\
\hline Minimum & 8.57 \\
\hline Std. Dev. & 28.8 \\
\hline Observation & 30 \\
\hline
\end{tabular}

Table1 provides summary statistics of the world crude oil prices. The result illustrates that the maximum price of crude oil prices were $98.99 \$$ in 2012 and the minimum price of it was 8.57\$ in 1999 . The mean and standard deviation of crude oil prices were $(40.20,28.8)$ respectively. Moreover, the data have been taken annually from 1990 to 2018 .

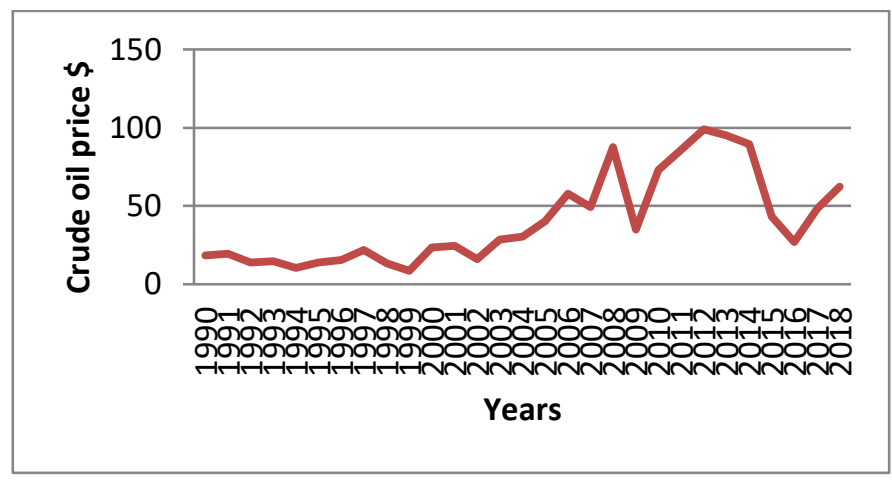

Figure 1: Time series plot of crude oil price in dollar per barrel from 1990-2018
It can be seen in the figure one that a graphical description of the oil price in dollar per barrel shows in this study. It presents the extreme changes of crude oil price in dollar during 1990 to 2018 in Iraq. Overall, there were justly consistent increases with a stable growth in crude oil price up until 2004. On the other hand, after 2004, there were extreme instability in the improvement of the crude oil price until 2008 to be more than $80 \$$ with the first huge dip in 2009 to be less than 40\$. However, after 2009 there were extremely increased the price of crude oil to be top in 2012 to approach $100 \$$. Then, pricing of crude oil decreased to be got less price in 2016 and after it gradually increased of price until 2018 .

Table (2): Test of the data

\begin{tabular}{|c|c|c|c|}
\hline \multicolumn{4}{|c|}{ Test for normality } \\
\hline $\begin{array}{c}\text { Jarque-Bera } \\
\text { Test }\end{array}$ & 1.143992 & P-value & 0.5644 \\
\hline \multicolumn{3}{|c|}{ Serial correlation LM test (Breusch- Godfrey) } \\
\hline $\begin{array}{c}\text { Obs R } \\
\text { Square }\end{array}$ & 0.4640 & $\begin{array}{c}\text { P-value } \\
\text { (chi- }\end{array}$ & 0.7929 \\
square) & \\
\hline Heteroskedasticity test (Breusch-Pagan- Godfrey) & 0.3991 \\
\hline $\begin{array}{c}\text { Obs R } \\
\text { Square }\end{array}$ & 153.7961 & $\begin{array}{c}\text { P-value } \\
\text { (chi- } \\
\text { square) }\end{array}$ & \\
\hline
\end{tabular}

As shown in the table (2) that Jarque-Bera test were used to test the normality of the data, it equals to (1.0143992) and p-value equals (0.5644) which were greater than the common alpha 0.05 this mean that the distribution of the data were normal. Moreover, Breusch- Godfrey test can be used to test serial correlation of the data, the Obs R Square equals to 0.4640 and p-value equals 0.7929 this means that there is no serial correlation of the data. Finally, the Breusch- Pagan- Godfrey were used to test heteroskedasticity of the data, the Obs $\mathrm{R}$ square equals 153.7961 and p-value equals 0.3991 this means that there is no affected by heteroskedasticity.

Table (3): Results of unit root tests: 2003-2013

\begin{tabular}{c|c|c} 
ADF & PPERRON & KPSS \\
\hline
\end{tabular}




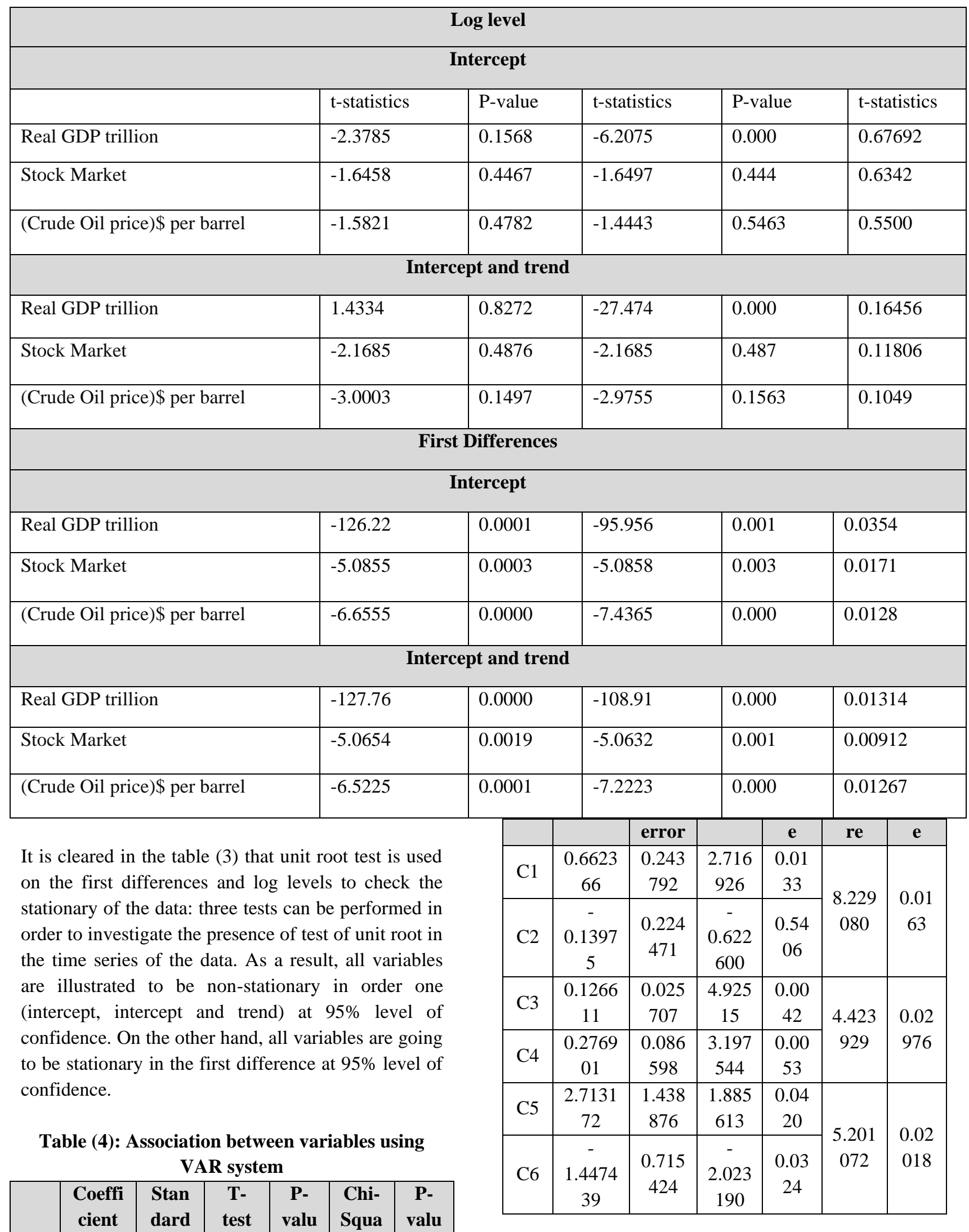




\begin{tabular}{|c|c|c|c|c|l|l|}
\hline C7 & $\begin{array}{c}1.1709 \\
13\end{array}$ & $\begin{array}{c}0.515 \\
972\end{array}$ & $\begin{array}{c}2.269 \\
333\end{array}$ & $\begin{array}{c}0.03 \\
545\end{array}$ & \\
\hline R- & sq & 0.9351 & F- & 48.04 & P- & \\
ua & 27 & test & 912 & $\begin{array}{c} \\
\text { valu } \\
\text { e }\end{array}$ & 0.000000 \\
\hline AI & - & \multicolumn{2}{|l}{ Durbin-watson stat } & 1.964924 \\
C & $\begin{array}{c}2.3919 \\
89\end{array}$ & & \\
\end{tabular}

C1, C2: lag one and two for stock market, C3, C4: lag one and two for oil price. C5, C6: lag one and two for GDP. C7: constant

It can be seen in the table (4) that both lagged period of GDP has positive influence on current period. The absolute value of the coefficient of the first period lag has a greater influence on GDP at current period than that of second order lag. Based on wald test both the lags can jointly influence itself. Moreover, Oil price has a positive influence. In the first and second lag has a positive influence on stock market at a current period. Thus, in the short term the increasing of oil price can rise of stock market. In the case of GDP, the first and second lagged period has statistically significance impact on stock market. In the first lag, GDP has a positive influence on stock market but the second lag GDP has a negative statistically significance on stock market. Thus, increasing of GDP in the first lag of GDP can rise of stock market but increasing of oil price in the second.

Therefore, the final model;

First lag $=1.170913+0.126611$ crude oil price + 2.713172 GDP

Second lag $=1.170913+0.276901$ crude oil price 1.447439 GDP

Until the second lag were chosen because it has the minimum significance Akaike information criterion (AIC) .In the first lag both variables had positive impact on stock market, but in the second the crude oil price had positive impact and GDP had negative impact on stock market which means that taking lag had a huge influence of variables. 
Response to Cholesky One S.D. (d.f. adjusted) Innovations \pm 2 S.E.

Response of STOCK_MARKET to STOCK_MARKET

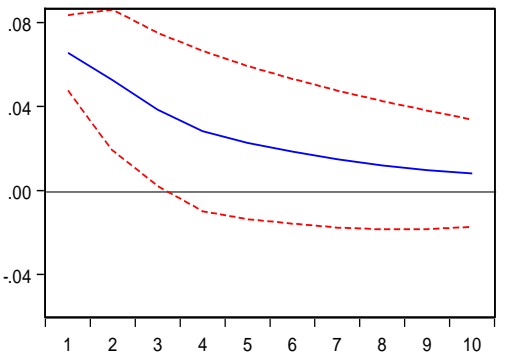

Response of GDP to STOCK_MARKET

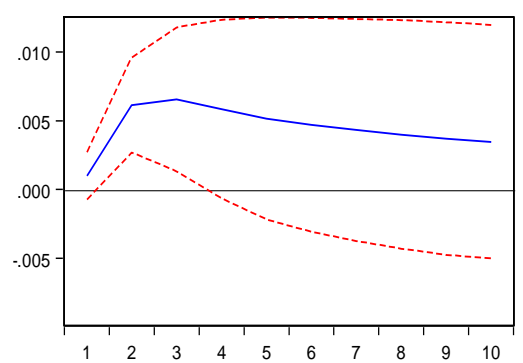

Response of OIL_PRICE to STOCK_MARKET

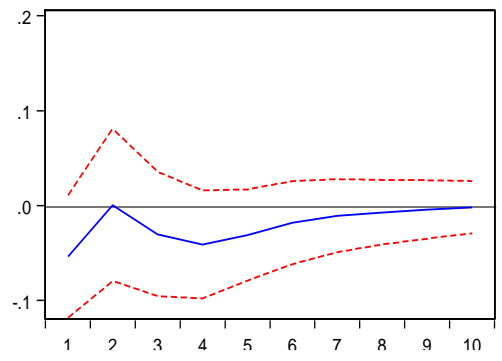

Response of STOCK_MARKET to GDP

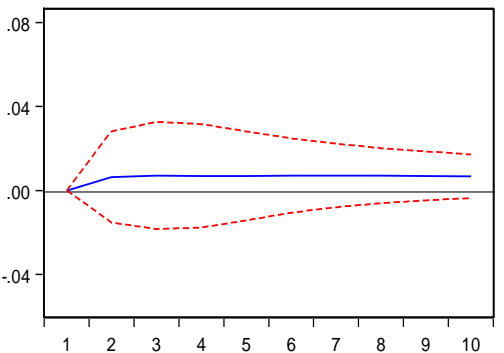

Response of GDP to GDP

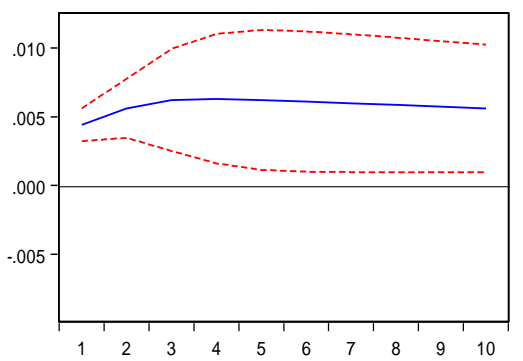

Response of OIL_PRICE to GDP

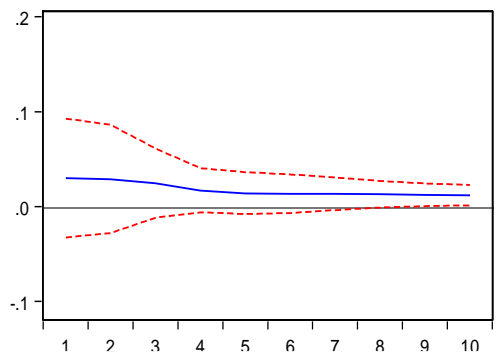

Response of STOCK_MARKET to OIL_PRICE

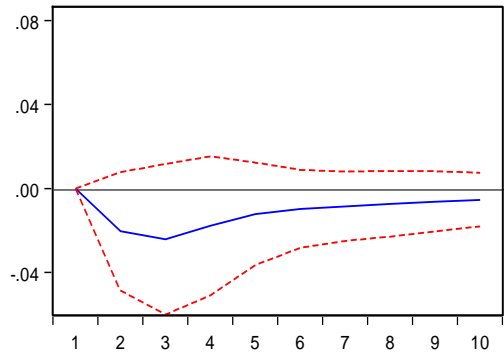

Response of GDP to OIL_PRICE

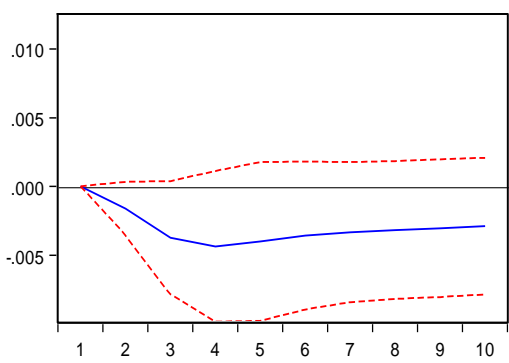

Response of OIL_PRICE to OIL_PRICE

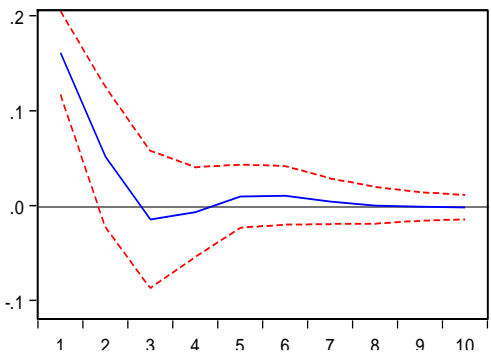

Figure (1): Graph of Impulse response functions (IRFs)

\section{Summary and Conclusion}

Based on a theoretical hypothesis and empirical investigations, this study provides comprehensive evidence of the connection between the dynamics of stock markets and oil prices. The analysis of this research focuses on the interactive relationship among the fluctuation of crude oil prices, the real GDP and the stock market of United State. Selected variables are stock market as a dependent variable while oil price and GDP were independent variables for US, and also the data was collected from time period 1990 to 2018 .
The VAR result shows that, in the first lag both variables had positive impact on stock market, but in the second the crude oil price had positive impact and GDP had negative impact on stock market, which means that taking lag had a huge influence of variables. Findings, oil price and economic growth are very important determinates of stock market in US because the p-value of this were less than the common alpha $\alpha=0.05$. For instance, the crude oil price had positive impact on stock market because for each unit increasing of crude oil price, the stock market will increase by (0.276901) after holding all other variable constant. However, we find that GDP 
variable has negative impact on the participations of increasing the stock market.

Any future research in this subject might appropriately target expanding the number of countries being studied, especially those emerging, since there is an inadequate quantity of research on those nations. In addition, it was initially one aim of the study to include the Iraqi stock market to see the effects of political instability on both stock market and oil prices. However, this was excluded due to the unavailability of data. I am aimed to further analyse this issue as soon as accurate data can be obtained.

\section{Reference}

[1] Adam, J. A., and Sanni, I., (2005). "Stock Market Development and Nigeria's Economic Growth'. Journal of Economics and Allied Fields, 2(2), pp. 116-132.

[2] Aloui, C., and Jammazi, R., (2009). "The effects of crude oil shocks on stock market shifts behaviour: A regime switching approach'. International Finance Group-Tunisia, Faculty of Management", Energy Economics, 31, PP. 789-799.

[3] Chen, N. F., Roll, R., and Ross, S.A., (1986). "Economic forces and the stock market", Journal of Business 59, 383-403.

[4] Gisser, M., and Goodwin, T. H., (1986). "Crude oil and the macroeconomy: Tests of some populations", Journal of Money Credit and Banking 18 (1), pp. 95-103.

[5] Hamid, M., and Sumit, A., (1998). "Stock Market Development and Economic Growth': Evidence from Developing Countries",Working paper, pp.1-19.

[6] Hamilton, J. D., (1983). "Oil and the macroeconomy since World War II", Journal of Political Economy 91, pp. 228-248.

[7] Hamilton, J. D. (2003). "What is an oil shock?" Journal of econometrics, 113(2): pp. 363-398.

[8] Huang, R. D., Masulis, R.W., and Stoll, H.R.,(1996). "Energy shocks and financial markets", Journal of Futures Markets 16, pp. $1-27$.

[9] Jones, C., Kaul, G., (1996). Oil and stock markets. The Journal of Finance. 51(2), pp. 463-491.

[10] Kapusuzoglu, A., (2011). "Relationships between Oil Price and Stock Market: An Empirical Analysis from Istanbul Stock Exchange (ISE)", International Journal of Economics and Finance, 3(6), pp. 99-106.

[11] Kilian, L., and Park, C., (2009). "The impact of oil price shocks on the U.S. stock market", International Economic Review 50, pp. 12671287.

[12] Maghyereh, A., (2004). Oil price shock and emerging stock markets: A Generalized VAR Approach", International Journal of Applied Econometrics and Quantitative Studies, 1(2), pp. 27-40.

[13] Park, J., and Ratti, R.A., (2008). "Oil price shocks and stock markets in the U.S. and 13 European countries", Energy Economics 30, pp. 2587-2608.

[14] Sadorsky, P., (1999). "Oil price shocks and stock market activity", Energy Economics, 21, pp. 449-469.

[15] Sim, C. A., (1980). "Macroeconomics and reality", Econometrica, 48(1), pp. 1-48.

[16] Vazakidis, A., (2009) "Stock Market Development and Economic Growth", American Journal of Applied Sciences, 6(11), PP. 1932-1940.

[17] Wei, C., (2003). "Energy, the Stock Market, and the Putty-Clay Investment model", American Economic Review, 93, pp. 311-323. 